\title{
Antibacterial activity of taro [Colocasia esculenta (L.) Schott] leaves extract against foodborne pathogens and its effect on microbial population in raw chicken meat
}

\author{
${ }^{1}$ Alzabt, A.M. and ${ }^{* 1,2}$ Rukayadi, Y. \\ ${ }^{1}$ Department of Food Science, Faculty of Food Science and Technology, Universiti Putra Malaysia, 43400 \\ UPM Serdang, Selangor, Malaysia \\ ${ }^{2}$ Laboratory of Natural Medicine, Institute of Bioscience, Universiti Putra Malaysia, 43400 UPM Serdang, \\ Selangor, Malaysia
}

\begin{abstract}
Article history:
Received: 20 September 2020 Received in revised form: 30 October 2020

Accepted: 1 January 2021 Available Online: 25 April 2021
\end{abstract}

\section{Keywords:}

Antibacterial activity, Colocasia esculenta (L.) Schott,

Foodborne pathogens, Microbial population, Natural food preservative

DOI:

https://doi.org/10.26656/fr.2017.5(2).523

\begin{abstract}
Chicken meat is one of the most consumed animal products worldwide. It is a favourable medium for bacterial growth due to its high moisture content and nitrogenous compounds. The growth of foodborne pathogens in food products can cause food poisoning and foodborne illness. Chemical preservatives act to restrict microbial growth which causes deterioration and spoilage of chicken meat and chicken meat products. Chemical preservatives, however, are not preferred nowadays due to consumer perception and their residual effect on the human body. Therefore, the interest in the development of plantbased bio preservatives as a natural alternative to chemical preservatives is increasingly gaining attention. This study aimed to evaluate the antimicrobial activity of taro [Colocasia esculenta (L.) Schott] leaves extract against foodborne pathogens, including Escherichia coli ATCC 43895, Listeria monocytogenes ATCC 19112, Salmonella enterica serovar Typhimurium ATCC 14028, and Staphylococcus aureus ATCC 29737, as well as its effect on microbial population in chicken meat at different concentrations and exposure times. Taro leaves powder was extracted by maceration methods using ethanol as a solvent. The crude extract was tested for antibacterial activity by means of disc diffusion assay (DDA), minimum inhibitory concentration (MIC), minimum bactericidal concentration (MBC), and time-kill curve analysis. The effects of the extract on microbial population were evaluated at different concentrations, exposure times and storage temperatures. The results showed the inhibition zone of the extract against tested bacterial ranged from $9.5 \pm 0.3 \mathrm{~mm}$ to $11.6 \pm 0.2 \mathrm{~mm}$. The extract can inhibit the growth and kill the tested bacteria with MIC and MBC of 2.50 and $5.00 \mathrm{mg} / \mathrm{mL}$, respectively. The time-kill curve analysis demonstrated that the extract can completely kill the tested bacteria at $4 \times$ MIC for $0.5 \mathrm{hrs}$. Approximately, 5\% of the extract could reduce all the microbial population in chicken meat samples with an exposure time of 30 mins. The result suggested that taro leaves extract (TLE) can be integrated into the food system as a natural food preservative.
\end{abstract}

\section{Introduction}

Food poisoning is considered a real concern that affects human health. Different organizations and authorities work on preventing or minimizing the causes of food poisoning. In Malaysia, the incident rate of food poisoning in 2009 was 36.17 per 100 thousand people (Puteh et al., 2013). Food poisoning is identified as a gastrointestinal or neurological illness. This illness happens due to food consumption in the previous $72 \mathrm{hrs}$, in which the same symptoms appear on two persons or more (Addis and Sisay, 2015). Food poisoning takes place when food is contaminated by bacteria, parasites, fungi, or viruses. Some bacteria are not harmed in small amount, in which the human immune system is responsible to fight them, but most of the food contamination takes place during the handling process, giving the pathogen the time, environment and supplement to multiply until it reaches a level, in which it can cause food poisoning.

Food preservatives and additives are used widely 
around the world. Food naturally has a short shelf life, in which pathogens, enzymes and other environmental factors make some changes in terms of safety and quality of food when time passes, such as spoilage, discolouration, and odour loss if no additives and preservatives were added to food. Due to this problem, human beings currently have learned to extend the food shelf life by freezing, drying, freeze-dry, or adding preservatives and food additives to eliminate or solve the aforementioned food issues (Sharma, 2015). Food additives have uncountable benefits, such as maintaining the quality of food, preventing the texture from loss or being damaged and extending the shelf life of food to keep it available for consumption any time in the year. Although using preservatives have some advantages, it also carries some disadvantages. For example, benzoate is a chemical preservative that is used in small amount, but it causes skin allergen, in which some cases are reported, as well as brain damage, is believed to be developed from consuming benzoate (Abdulmumeen et al., 2014). Sometimes, the chemical preservatives that are used in food industries are Generally Recognized as Safe (GRAS), but they are still under concern, in which customers try to look for safer preservatives from green resources. At present, industries tend to use natural preservatives that are extracted from natural sources, such as medical or edible plants to keep the food pure from man-made chemicals and make their customers satisfied (Bondi et al., 2017).

Colocasia esculenta (L.) Schott or taro from the Araceae family is an edible plant that is known for its nutrients and its ability to cure diseases. Traditionally, taro leaves are used for healing internal haemorrhages, adenitis and otalgia (Pawar et al., 2018). The leaves are rich in nutrients, including minerals, such as Calcium, Phosphorous and Iron, as well as vitamins, like vitamin C, Thiamine, Riboflavin, and Niacin. As such, leaves are valuable sources of proteins and dietary fibres (Nakade et al., 2013). Taro leaves are used as a poultice for healing wounds (Singh et al., 2011). Due to the benefits of taro leaves as an edible and medical plant, the aim of this study is to evaluate the antibacterial activity of taro leaves extracts against selected foodborne pathogens, as well as its effects on microbial population in chicken meat at different concentrations, exposure times and storage temperatures.

\section{Materials and methods}

\subsection{Taro leaves and chicken meat samples}

Fresh taro leaves were obtained from Taman Pertanian, Universiti Putra Malaysia. Collecting the samples of taro leaves was carried out in June 2018 .
Chicken meat was purchased from Pasar Malam Sri Serdang in Selangor, Malaysia. The chicken meat was wrapped in several layers of polyvinyl chloride (PVC) plastic and kept in an iced container before transferring it to the laboratory's chiller within one hour of purchasing time.

\subsection{Extraction of taro leaves}

The fresh leaves were fully dried using a hot air oven at $55^{\circ} \mathrm{C}$. The dried leaves were crushed into a powdered form using a stainless-steel grinder. The extraction was carried out by following the method of Rukayadi et al. (2008) with some modifications. Briefly, $100 \mathrm{~g}$ of leaves powder was soaked in $400 \mathrm{~mL}$ of $95.0 \%$ ethanol for 24 hrs at $40^{\circ} \mathrm{C}$ in a water bath shaker at $110 \mathrm{rpm}$. After that, vacuum filtration was used to obtain the crude leaves extract. The crude extract was concentrated using a rotary evaporator (Heidolph VV2011, Schwabach, Germany) at $55^{\circ} \mathrm{C}$ and $110 \mathrm{rpm}$. The ethanol-free extract was then stored in a chiller at $4^{\circ} \mathrm{C}$ for further analysis.

\subsection{Preparation of crude extract and bacterial strains}

A $100 \mathrm{mg}$ of crude extract was diluted in $100 \%$ dimethyl sulfoxide (DMSO) (Sigma-Aldrich, USA) to obtain $10 \%$ of crude extract, and then, it was diluted in sterile distilled water $\left(\mathrm{dH}_{2} \mathrm{O}\right)$. In the end, the final concentrations were $1 \%$ of crude extract and $10 \%$ of DMSO. The $10 \%$ of DMSO did not affect the growth of the tested bacteria, and this solution was used as a negative control in the antibacterial activity test. Approximately $1 \%$ of chlorhexidine gluconate (CHX) (Sigma-Aldrich, USA) was used as a positive control.

A total of four species of foodborne pathogens were used in this study, namely, Escherichia coli ATCC 43895, Listeria monocytogenes ATCC 19112, Salmonella enterica serovar Typhimurium ATCC 14028, and Staphylococcus aureus ATCC 29737 due to the fact that some of these bacterial contaminants could survive or grow during handling, processing or storage. All bacterial species were obtained from American Type Culture Collection (Rockville, MD, USA). All the test strains were sub-cultured on Muller Hinton Agar (MHA) (Difco Becton Dickinson, Sparks, MD, USA), incubated at $37^{\circ} \mathrm{C}$ for $24 \mathrm{hrs}$ and stored at $4^{\circ} \mathrm{C}$ in a refrigerator to maintain stock culture.

\subsection{Antibacterial activity test}

\subsubsection{Disc diffusion assay (DDA)}

DDA was conducted with the method as described by Clinical and Laboratory Standard Institute (CLSI) (2012). Briefly, an overnight culture of each strain was spread on the Muller Hinton agar (MHA) (Difco Becton 
Dickinson, Sparks, MD, USA) using a sterile cotton swab. Sterile paper disc (D: $6 \mathrm{~mm}$ ) was placed onto MHA and impregnated with $10 \mu \mathrm{L}$ of $1 \%$ crude extract. A negative control (10\% of DMSO) and positive control ( $1 \%$ of $\mathrm{CHX})$ were included in this experiment. All the plates were then incubated at $37^{\circ} \mathrm{C}$ for $24 \mathrm{hrs}$. The experiment was carried out three times in duplicates. The diameter of zones of inhibition formed was measured and their average was determined using the method as reported by the Clinical and Laboratory Standards Institute (CLSI, 2012). A clear inhibition zone around the impregnated disc was an indication of the presence of antibacterial activity.

\subsubsection{Minimum inhibitory concentration (MIC) and Minimum bactericidal concentration $(M B C)$}

The minimum inhibitory concentration (MIC) of taro leaves extract for each isolate was performed on Muller Hinton broth (MHB) (Difco Becton Dickinson, Sparks, MD, USA) according to Clinical and Laboratory Standard Institute M7-A9 (CLSI, 2012) with a slight modification. This test was performed in a sterile 96-well microtiter plate using a two-fold standard broth microdilution method. The two-fold dilution of $1 \%$ taro leaves extract solution mixed with the bacterial isolates in MHB was filled in the 96- well microtiter. The first columns of the wells were filled with $100 \mu \mathrm{L}$ of MHB which served as a negative control growth. The second columns, which were the positive control growth columns, were filled with $100 \mu \mathrm{L}$ of the bacterial suspension. The microdilution was performed at concentration ranged from $5 \mathrm{mg} / \mathrm{mL}$ in column twelve to $0.01 \mathrm{mg} / \mathrm{mL}$ in column three. The microtiter plate was later incubated at $37^{\circ} \mathrm{C}$ for $24 \mathrm{hrs}$. Talaro and Chess (2012) elucidated that MIC could be interpreted as the lowest concentration of the antibacterial agent that visually inhibited the growth of microorganisms after overnight incubation. The first well with no visible growth after the incubation period was taken as MIC.

The minimum bactericidal concentration (MBC) was the minimal concentration of antibacterial that killed the inoculums and could be determined from broth dilution MIC test by sub-culturing it into MHA medium (approximately $10 \mu \mathrm{L}$ ) without any antibacterial agents (French, 2006; Rukayadi et al., 2009). A volume of 10 $\mu \mathrm{L}$ from all the wells from column one to twelve was pipetted onto the agar plates. The plate was then incubated at $37^{\circ} \mathrm{C}$ for $24 \mathrm{hrs}$. MBC was defined as the lowest concentration with no growth on MHA plates or the lowest concentration of the antibacterial agent.

\subsubsection{Time-kill curves analysis}

The time-kill assay study of taro leaves extract was carried out to assess the killing rate of the extract within a given contact time. In this study, the assay was done according to the CLSI reference method (2012) with a slight modification. The extract of $C$. esculenta L. leaves with different concentration $(0 \times \mathrm{MIC}, 1 \times \mathrm{MIC}, 2 \times \mathrm{MIC}$, $4 \times \mathrm{MIC}$ ) was mixed with inoculum. All the isolates were incubated at $37^{\circ} \mathrm{C}$ with $150 \mathrm{rpm}$ agitation at predetermined time points $(0,15$ and 30 mins, as well 1 , 2 and $4 \mathrm{hrs})$. Aliquots $(100 \mu \mathrm{L})$ were removed from each concentration at each of the time points and spread on the MHA medium. The plate was then incubated at $37^{\circ} \mathrm{C}$ for $24 \mathrm{hrs}$. After incubation, the agar plates were observed visually for the presence of growth. The number of colonies formed on the plate was counted, and the number was recorded as $\log _{10}(\mathrm{CFU} / \mathrm{mL})$. The assays were carried out two times in duplicate. Time-kill curves were constructed by plotting the $\log _{10} \mathrm{CFU} / \mathrm{mL}$ versus time (Rukayadi et al., 2009).

\subsection{Effect of taro leaves extract on microbial population in raw chicken meat}

\subsubsection{Treatment of raw chicken meat with different concentration of taro leaves extract}

Preparation of taro leaves extract for raw chicken meat treatment were conducted by following the method reported by Yusoff et al. (2015) with some modifications. A total of five samples of chicken meat were treated as follows: $0.00 \%$ (tap water), $0.00 \%$ (sterilized distilled water) and taro leaves extract at the concentration of $0.05 \%, 0.50 \%$ and $5.00 \%$ respectively. All samples were stored at different temperatures $\left(24 \pm 2^{\circ}\right.$ $\mathrm{C}$ and $\left.4 \pm 2^{\circ} \mathrm{C}\right)$ and exposure times $(0,15$ and 30 mins $)$ in a highly hygienic environment. Briefly, 10 grams of chicken meat was marinated with $10 \mathrm{~mL}$ of different concentrations of the extract. Then, samples were homogenized in a stomacher bag (BAGLIGHT, BagSysytem, Interscience, France) using a stomacher (BagMixer 400-P, Interscience, France) for 2 mins. Subsequently, a serial dilution was made up for each sample. After that, $10 \mu \mathrm{L}$ of each dilution was pipetted on the agar surface of the selective media and incubated for $24 \mathrm{hrs}$ at $37^{\circ} \mathrm{C}$. The number of colonies was counted and calculated as colony forming unit (CFU) per mL. All the experiments were carried out for two times in duplicate.

\subsubsection{Total plate count}

Total plate count was detected and enumerated using Plate Count Agar (PCA) (OXOID, Hamsphire, United Kingdom). An amount of $17.5 \mathrm{~g}$ of PCA was weighed and mixed with one litre of distilled water. The mixture was properly stirred and then sterilized at $121^{\circ} \mathrm{C}$ for 15 mins. The sterilized solution was left to be cooled down before being poured into a sterile petri dish. A 
volume of $0.1 \mathrm{~mL}$ of $10^{-2}$ until $10^{-4}$ dilutions was spread onto duplicate PCA plates. Then, plates were incubated in aerobic conditions at $37^{\circ} \mathrm{C}$ for $48 \mathrm{hrs}$. The logarithm numbers of colony forming unit per grams $\left(\log _{10} \mathrm{CFU} /\right.$ g) of samples were calculated by observing and enumerating the total colonies formed after incubation.

\subsubsection{Escherichia coli}

Escherichia coli was detected and enumerated using Eosin Methylene Blue (EMB) (CRITERION, Santa Maria, USA) agar. An amount of $37.5 \mathrm{~g}$ of EMB agar was weighed and mixed with one litre of distilled water. The mixture was properly stirred and then sterilized at $121^{\circ} \mathrm{C}$ for 15 mins. The sterilized solution was left to be cooled down before being poured into a sterile petri dish. A volume of $0.1 \mathrm{~mL}$ of $10^{-2}$ until $10^{-4}$ dilutions was spread onto triplicate of EMB agar. Then, plates were incubated in aerobic conditions at $37^{\circ} \mathrm{C}$ for $24 \mathrm{hrs}$. The logarithm numbers of colony forming unit per grams $\left(\log _{10} \mathrm{CFU} / \mathrm{g}\right)$ of samples were calculated by observing and enumerating the total colonies formed after incubation.

\subsubsection{Salmonella enterica serovar Typhimurium}

S. enterica ser. Typhimurium was detected and enumerated using Xylene Lysine Deoxycholate (XLD) (DifcoTM, Becton, Dickinson and Company Sparks, USA) agar. An amount of $55.0 \mathrm{~g}$ of XLD agar was weighed and mixed with one litre of distilled water. The mixture was properly stirred until it boiled. The solution was left to be cooled down before being poured into a sterile petri dish. A volume of $0.1 \mathrm{~mL}$ of $10^{-2}$ until $10^{-4}$ dilutions was spread onto triplicate of XLD agar. Then, plates were incubated in aerobic conditions at $37^{\circ} \mathrm{C}$ for $24 \mathrm{hrs}$. The logarithm numbers of colony forming unit per grams $\left(\log _{10} \mathrm{CFU} / \mathrm{g}\right)$ of samples were calculated by observing and enumerating the total colonies formed after incubation.

\subsubsection{Staphylococcus aureus}

Staphylococcus aureus was enumerated using Mannitol Salt Agar (MSA) (OXOID, Hamsphire, United Kingdom). An amount of 108.0 grams of MSA was weighed and mixed with one litre of distilled water. The mixture was properly stirred and then sterilized at $121^{\circ} \mathrm{C}$ for 15 mins. The sterilized solution was left to be cooled down before being poured into a sterile petri dish. A volume of $0.1 \mathrm{~mL}$ of $10^{-2}$ until $10^{-4}$ dilutions was spread onto triplicate of MSA. Then, plates were incubated in aerobic conditions at $37^{\circ} \mathrm{C}$ for $48 \mathrm{hrs}$. The logarithm numbers of colony forming unit per grams ( $\log _{10} \mathrm{CFU} /$ g) of samples were calculated by observing and enumerating the total colonies formed after incubation.

\subsection{Statistical Analysis}

Minitab software (version 16.0) was used to analyse the data for the analysis of variance (one-way ANOVA). Turkey's test was used to determine the significant difference $(p<0.05)$. Data expressed as means of duplicates \pm standard deviations were carried out using Excel software.

\section{Results and discussion}

\subsection{Yield of Extraction}

A total of $100 \mathrm{~g}$ of taro leaves powder was extracted by absolute ethanol and the net weight that was obtained from the extraction process was five grams. With regards to two different studies that had performed extraction for C. esculenta leaves, their extraction yields were four and nine grams respectively (Akter et al., 2013; Dutta, 2017). The mentioned studies used methanol as a solvent, in which each step before and during the extraction process, such as grinding, drying, soaking, and evaporation played a vital role in the final net weight, as well as the contents (Azwanida, 2015).

\subsection{Antibacterial activity test}

\subsubsection{Disc diffusion test (DDA)}

DDA test uncovered that using $10 \mathrm{mg} / \mathrm{mL}$ of taro leaves extract resulted in inhibition zones of $9.75 \pm 0.30$ $\mathrm{mm}$ for $E$. coli, $S$. enterica ser. Typhimurium, $12.25 \pm 0.30 \mathrm{~mm} \mathrm{~L}$. monocytogenes and $11.65 \pm 0.20 \mathrm{~mm}$ S. aureus (Table 1). However, in the case of the positive control (CHX), the observed inhibition zones were $11.00 \pm 0.0 \mathrm{~mm}$ for $E$. coli and $S$. enterica ser. Typhimurium, $14.50 \pm 0.0 \mathrm{~mm}$ for L. monocytogenes and

Table 1. Inhibition zone ( $\mathrm{mm}$ ) of taro (Colocasia esculenta) leaves extract against selected foodborne pathogens

\begin{tabular}{|c|c|c|c|}
\hline \multirow{2}{*}{ Bacteria strain } & \multicolumn{3}{|c|}{ Inhibition zone (mm) } \\
\hline & TLE $1.0 \%$ & CHX $1.0 \%$ & DMSO $10.0 \%$ \\
\hline Escherichia coli ATCC 43895 & $9.7 \pm 0.3$ & $11.0 \pm 0.0$ & 0 \\
\hline Listeria monocytogenes ATCC 19112 & $12.2 \pm 0.3$ & $14.0 \pm 0.0$ & 0 \\
\hline Salmonella enterica ser. Typhimurium ATCC 14028 & $9.7 \pm 0.3$ & $11.0 \pm 0.0$ & 0 \\
\hline Staphylococcus aureus ATCC 29737 & $11.6 \pm 0.2$ & $15.0 \pm 0.0$ & 0 \\
\hline
\end{tabular}

*Values are expressed as mean \pm standard deviation.

* Inhibition zone includes the diameter of disc paper (6 mm). 
$15.25 \pm 0.30 \mathrm{~mm}$ for $S$. aureus. In the study of Dubey et al. (2010), $20 \mathrm{mg} / \mathrm{mL}$ of C. esculneta methanolic extract showed the inhibition zones of $18 \mathrm{~mm}$ and $20 \mathrm{~mm}$ for $E$. coli and $S$. aureus, respectively. Nevertheless, Geetha et al. (2015) revealed that the inhibition zone of $S$. enterica ser. Typhimurium was $10 \mathrm{~mm}$ using $25 \mathrm{mg} / \mathrm{mL}$ of $C$. esculenta methanol extract, while the ethanolic extract exhibited the inhibition zones of 10,14 and $12 \mathrm{~mm}$ for $E$. coli, $S$. enterica ser. Typhimurium and $S$. aureus. Even though the current study displayed less antibacterial activity using $10 \mathrm{mg} / \mathrm{mL}$ of taro leaves extract as compared with the previous studies, the results indicated that taro leaves extract had antibacterial activity even at low concentrations.

\subsubsection{Minimum inhibitory concentration (MIC) and minimum bactericidal concentration (MBC)}

MIC and MBC tests were conducted to investigate the minimum inhibitory and bactericidal concentrations of taro leaves extract. The obtained values of MIC and MBC for tested pathogens were $2.50 \mathrm{mg} / \mathrm{mL}$ and 5.0 $\mathrm{mg} / \mathrm{mL}$ respectively (Table 2). Nakade et al. (2013) focused their study on the antimicrobial activity of methanolic extract of $C$. esculenta leaves, in which MIC results for E. coli and S. aureus were $1.3 \mathrm{mg} / \mathrm{mL}$ and $2.5 \mathrm{mg} / \mathrm{mL}$ respectively. Moreover, Lee et al. (2011) found that the MIC value for S. enterica ser. Typhimurium was at $0.5 \mathrm{mg} / \mathrm{mL}$, which used different portions of $C$. esculenta extracts leaves. These leaves had a variety of chemical compounds and different capabilities to inhibit bacterial growth or kill pathogens (Geetha et al., 2015). Nonetheless, it seemed that using different solvents in extraction may affect the activity of the final product.

\subsubsection{Time-kill curves analysis}

The antibacterial activity of taro leaves extract was tested on foodborne pathogens and the results of MIC were used in terms of determining the real time kill for each pathogen. To present an antibacterial effect, different concentrations of the extract at and above the MIC values were applied on bacteria. The results are shown in Figures 1 to 4 . Figures 1 to 4 illustrate the time kill analyses of pathogens exposed to different concentrations of extract $(0 \times \mathrm{MIC}, 1 \times \mathrm{MIC}, 2 \times \mathrm{MIC}$, and $4 \times \mathrm{MIC})$. At the highest concentration of taro leaves extract $4 \times \mathrm{MIC}$, it was found that all tested pathogens were completely killed within 30 mins of exposing time. At $1 \times \mathrm{MIC}$ L. monocytogenes (Figure 2) and S. enterica ser. Typhimurium (Figure 3) were inhibited because of using the extract. However, this inhibition was only for a short period because L. monocytogenes and S. enterica ser. Typhimurium grew back again. This temporary inhibition may be interpreted as shock from exposure to the extract. The extract at $2 \times \mathrm{MIC}$ had some inhibitions against $S$. aureus (see Figure 4) within the given testing period, but it may need more time to record a significant inhibition. This was because at $4 \times \mathrm{MIC}$ of concentration, the pathogen was completely killed within 30 mins only. Furthermore, E. coli (Figure 1), L. monocytogenes (Figure 2) and $S$. enterica ser. Typhimurium (Figure 3) were completely killed within four hrs at $2 \times \mathrm{MIC}$ of taro leaves concentration.

Time kill analyses had been widely used in uncountable studies to discover new antimicrobial agents among plants (Oladosu et al., 2019). Some planets had a high effect on bacterial growth, and they exhibited bactericidal activity even at very low concentrations. Fu et al. (2007) study that used essential oils extracted from clove and rosemary had significant bactericidal activity against $E$. coli. E. coli was completely killed after $12 \mathrm{hrs}$ using $0.50 \%$ of concentration of rosemary essential oil, while at $0.25 \%$ and $0.12 \%$ of concentrations of clove essential oil, the tested bacteria were killed after half an hour and eight hrs respectively. Comparing with rosemary and clove essential oils, taro leaves extract in the present study had a lethal effect on E. coli, in which it was completely killed after 2 and 4 hrs of treatment at $0.5 \%$ and $1.0 \%$ of concentrations, respectively. Thus, taro leaves extract at $0.5 \%$ of concentration demonstrated that the bactericidal activity against $E$. coli was faster than both clove and rosemary essential oils. Rosemary extraction was used as an antilisterial agent in the study that was conducted by Bubonja et al. (2011) as well as other studies that included rosemary, olive oil and cocoa extracts. The different extracts had shown different activities against L. monocytogenes. Rosemary had the highest activity during the study, while cocoa had almost no activity as antilestiria. In the time kill test, rosemary and olive oil extracts had reduced the number of forming colony from $6 \log _{10}$ to $2 \log _{10}$ after three and eight hrs at $0.03 \mathrm{mg} / \mathrm{mL}$ and $0.8 \mathrm{mg} / \mathrm{mL}$ of extract concentrations,

Table 2. Minimum inhibitory concentration (MIC) and minimum bactericidal concentration (MBC) of taro (Colocasia esculenta) leaves extract against selected foodborne pathogens

\begin{tabular}{ccccc}
\hline Bacteria strain & \multicolumn{2}{c}{ TLE $(\mathrm{mg} / \mathrm{mL})$} & \multicolumn{2}{c}{ CHX $(\mathrm{mg} / \mathrm{mL})$} \\
\cline { 2 - 5 } & MIC & MBC & MIC & MBC \\
\hline Escherichia coli ATCC 43895 & 2.5 & 5 & 0.62 & 1.25 \\
Listeria monocytogenes ATCC 19112 & 2.5 & 5 & 0.04 & 0.08 \\
Salmonella enterica ser. Typhimurium ATCC 14028 & 2.5 & 5 & 0.31 & 0.62 \\
Staphylococcus aureus ATCC 29737 & 2.5 & 5 & 0.08 & 0.15 \\
\hline
\end{tabular}




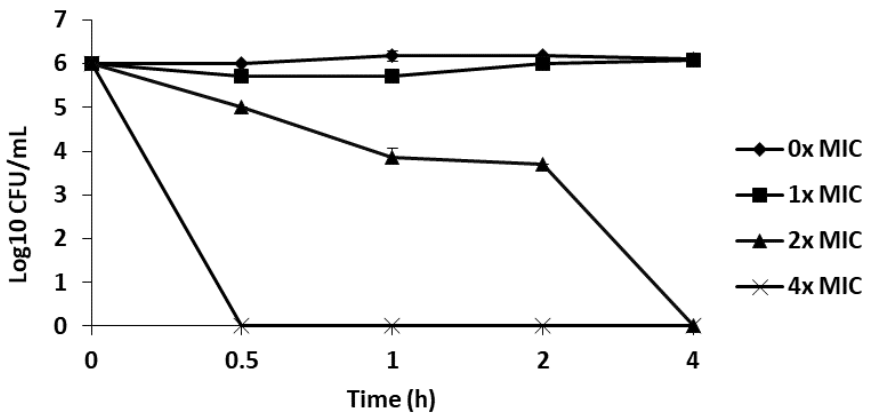

Figure 1. E. coli time-kill curve exposed to $0 \times \mathrm{MIC}, 1.0 \times \mathrm{MIC}$, $2.0 \times \mathrm{MIC}$, and $4.0 \times \mathrm{MIC}$ of TLE for 0 to $4 \mathrm{hrs}$ incubation time

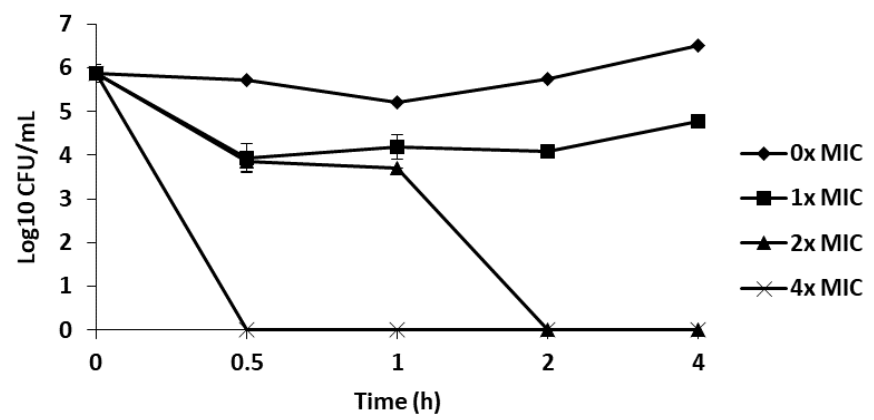

Figure 3. S. enterica ser. Typhimurium time-kill curve exposed to $0 \times \mathrm{MIC}, 1.0 \times \mathrm{MIC}, 2.0 \times \mathrm{MIC}$, and $4.0 \times \mathrm{MIC}$ of TLE for 0 to 4 hrs incubation time

respectively. The current study exhibited bactericidal activity against $L$. monocytogenes using taro leaves extract at $5.0 \mathrm{mg} / \mathrm{mL}$ and $2.5 \mathrm{mg} / \mathrm{mL}$ after 30 mins and eight hrs of exposing time. Therefore, taro leaves extract may have more bactericidal activities than rosemary and olive oil extracts. Mamman et al. (2013) tested Azadirachta indica extract on Salmonella spp. in terms of time kill at different concentrations and exposing time to investigate the possible bactericidal activity. The study results showed a lethal effect on Salmonella spp. at 175 $\mathrm{mg} / \mathrm{mL}$ concentration of $A$. indica extract after $10 \mathrm{mins}$ of exposing time. It was proven that taro leaves extract had bactericidal activity against $S$. enterica ser. Typhimurium at a much lower concentration than $A$. indica extract, in which taro leaves extract had the ability to kill $S$. enterica ser. Typhimurium completely at 5.0 $\mathrm{mg} / \mathrm{mL}$ and $2.5 \mathrm{mg} / \mathrm{mL}$ after $30 \mathrm{mins}$ and four hrs of exposing time. In a study done by Palombo and Semple (2002), ethanolic extract of Eremophila alternifolia leaves and Lepidosperma viscidum stem was applied on methicillin-resistance $S$. aureus to investigate antibacterial activity of selected extracts using time kill test. E. alternifolia and L. viscidum extracts at $0.80 \mathrm{mg} /$ $\mathrm{mL}$ and $0.48 \mathrm{mg} / \mathrm{mL}$ exhibited inhibition activity against $S$. aureus within four hrs and reduced the number of cell colonies 4- $\operatorname{logs}$ and 6-logs respectively. The present study used taro leaves extract that revealed bactericidal activity against $S$. aureus at $2.5 \mathrm{mg} / \mathrm{mL}$ and $5.0 \mathrm{mg} / \mathrm{mL}$ within two and four hrs respectively. In contrast, the differences among plants and their components, as well

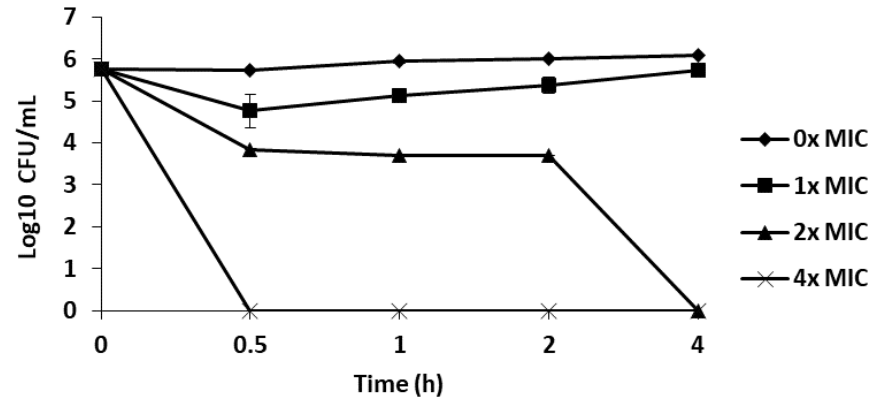

Figure 2. L. monocytogenes time-kill curve exposed to $0 \times \mathrm{MIC}, 1.0 \times \mathrm{MIC}, 2.0 \times \mathrm{MIC}$, and $4.0 \times \mathrm{MIC}$ of TLE for 0 to 4 hrs incubation time

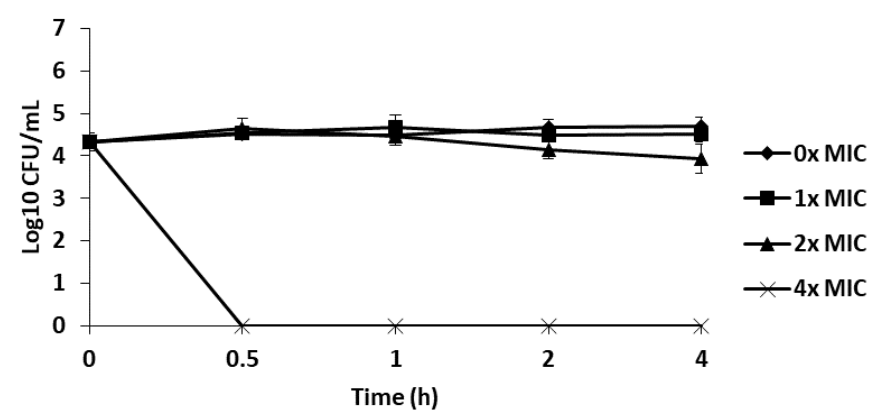

Figure 4. S. aureus time-kill curve exposed to $0 \times \mathrm{MIC}, 1.0 \times$ MIC, $2.0 \times \mathrm{MIC}$, and $4.0 \times \mathrm{MIC}$ of TLE for 0 to $4 \mathrm{hrs}$ incubation time.

as secondary metabolite products were an addition to the speed ratio of bacterial growth. All these factors created a variation among studies related to antimicrobial activity tests and final results (Fu et al., 2007).

\subsection{Effect of taro leaves extract on microbial population in raw chicken meat}

The extract at different concentrations and exposing time was applied on different parts of chicken meat at both room temperature $\left(24 \pm 2^{\circ} \mathrm{C}\right)$ and chiller temperature $\left(4 \pm 2^{\circ} \mathrm{C}\right)$ to determine the extract effects on population bacteria on chicken meat. Chicken samples were treated by taro leaves at $5.00 \%, 0.50 \%, 0.05 \%$, and $0.00 \%$ of concentrations, as well as sterile tap water for 0,15 and 30 mins. The results of the experiments were measured by counting formed colonies on TPC fresh agar and other selective media (Tables 3 and 4). The significance of difference $(\mathrm{p}<0.05)$ between those treatments and the level of significant difference between each treatment among the results were measured using Turkey's test as displayed in Tables 3 and 4 below. In the present study, the following pathogens were discovered in the chicken meat samples, including E. coli (clear metallic green sheen colonies on EMBa), Salmonella (Black centre colonies on XLD) and S. aureus (Yellow zones around yellow colonies on MSA). Results of TPC indicated that $5.00 \%$ of the concentration of taro leaves extract at chiller and room temperature had the ability to reduce 3logs from population bacteria in chicken meat after 30 mins of treating. At chiller treatment, E. coli, Salmonella 
Table 3. Effects of different taro (Colocasia esculenta) leaves extract concentrations and exposure times on microbial population in chicken meat at chiller $(\log 10 \mathrm{CFU} / \mathrm{g})$

\begin{tabular}{|c|c|c|c|c|c|c|}
\hline \multirow{2}{*}{ Bacterial species } & \multirow{2}{*}{$\begin{array}{c}\mathrm{ET} \\
(\mathrm{min})\end{array}$} & \multicolumn{5}{|c|}{ Treatment } \\
\hline & & Tap water & $0.00 \%$ extract & $0.05 \%$ extract & $0.50 \%$ extract & $5.00 \%$ extract \\
\hline \multirow{3}{*}{ Total Plate Count } & 0 & $5.80 \pm 0.05^{\mathrm{aA}}$ & $6.10 \pm 0.09^{\mathrm{bA}}$ & $6.20 \pm 0.09^{\mathrm{bA}}$ & $6.40 \pm 0.12^{\mathrm{bA}}$ & $6.40 \pm 0.21^{\mathrm{bA}}$ \\
\hline & 15 & $5.70 \pm 0.02^{\mathrm{aA}}$ & $6.90 \pm 0.07^{\mathrm{bA}}$ & $6.60 \pm 0.12^{\mathrm{bA}}$ & $5.70 \pm 0.11^{\mathrm{aB}}$ & $5.90 \pm 0.07^{\mathrm{aB}}$ \\
\hline & 30 & $5.80 \pm 0.06^{\mathrm{aA}}$ & $7.40 \pm 0.15^{\mathrm{bB}}$ & $6.90 \pm 0.24^{\mathrm{bB}}$ & $5.20 \pm 0.17^{\mathrm{aB}}$ & $3.20 \pm 0.02^{\mathrm{cC}}$ \\
\hline \multirow{3}{*}{ Escherichia coli } & 0 & $3.90 \pm 0.00^{\mathrm{aA}}$ & $3.90 \pm 0.02^{\mathrm{aA}}$ & $3.90 \pm 0.00^{\mathrm{aA}}$ & $0^{\mathrm{bA}}$ & $0^{\mathrm{bA}}$ \\
\hline & 15 & $3.90 \pm 0.00^{\mathrm{aA}}$ & $4.10 \pm 0.11^{\mathrm{bA}}$ & $4.08 \pm 0.12^{\mathrm{aA}}$ & $0^{\mathrm{cA}}$ & $0^{\mathrm{cA}}$ \\
\hline & 30 & $3.90 \pm 0.00^{\mathrm{aA}}$ & $4.70 \pm 0.15^{\mathrm{bB}}$ & $4.20 \pm 0.09^{\mathrm{bB}}$ & $0^{\mathrm{cA}}$ & $0^{\mathrm{cA}}$ \\
\hline \multirow{3}{*}{$\begin{array}{c}\text { Salmonella enterica ser. } \\
\text { Typhimurium ATCC } \\
14028\end{array}$} & 0 & $4.70 \pm 0.00^{\mathrm{aA}}$ & $4.20 \pm 0.09^{\mathrm{aA}}$ & $4.20 \pm 0.00^{\mathrm{aA}}$ & $4.20 \pm 0.09^{\mathrm{aA}}$ & $0^{\mathrm{bA}}$ \\
\hline & 15 & $4.70 \pm 0.00^{\mathrm{aA}}$ & $4.50 \pm 0.04^{\mathrm{aA}}$ & $4.30 \pm 0.08^{\mathrm{aA}}$ & $0^{\mathrm{bB}}$ & $0^{\mathrm{bA}}$ \\
\hline & 30 & $4.70 \pm 0.00^{\mathrm{aA}}$ & $4.50 \pm 0.04^{\mathrm{aA}}$ & $4.70 \pm 0.08^{\mathrm{aA}}$ & $0^{\mathrm{bB}}$ & $0^{\mathrm{bA}}$ \\
\hline \multirow{3}{*}{ Staphylococcus aureus } & 0 & $4.10 \pm 0.10^{\mathrm{aA}}$ & $4.60 \pm 0.34^{\mathrm{aA}}$ & $4.10 \pm 0.12^{\mathrm{aA}}$ & $4.40 \pm 0.06^{\mathrm{aA}}$ & $0^{\mathrm{bA}}$ \\
\hline & 15 & $4.40 \pm 0.08^{\mathrm{aA}}$ & $4.90 \pm 0.00^{\mathrm{aA}}$ & $4.30 \pm 0.00^{\mathrm{aA}}$ & $4.20 \pm 0.34^{\mathrm{aA}}$ & $0^{\mathrm{bA}}$ \\
\hline & 30 & $4.90 \pm 0.08^{\mathrm{aA}}$ & $5.27 \pm 0.10^{\mathrm{bB}}$ & $4.30 \pm 0.00^{\mathrm{acA}}$ & $3.90 \pm 0.12^{\mathrm{cB}}$ & $0^{\mathrm{dA}}$ \\
\hline
\end{tabular}

Values are expressed as mean \pm SD. Values with different lowercase superscript within the same row while values with different uppercase superscript within the same columns are significantly different $(\mathrm{p}<0.05)$.

Table 4. Effects of different taro (Colocasia esculenta) leaves extract concentrations and exposure times on microbial population in raw chicken meat at room temperature $(\log 10 \mathrm{CFU} / \mathrm{g})$

\begin{tabular}{|c|c|c|c|c|c|c|}
\hline \multirow{2}{*}{ Bacterial species } & \multirow{2}{*}{$\begin{array}{c}\text { ET } \\
(\min )\end{array}$} & \multicolumn{5}{|c|}{ Treatment } \\
\hline & & Tap water & $0.00 \%$ extract & $0.05 \%$ extract & $0.50 \%$ extract & $5.00 \%$ extract \\
\hline \multirow{3}{*}{ Total Plate Count } & 0 & $5.81 \pm 0.08^{\mathrm{aA}}$ & $6.54 \pm 0.10^{\mathrm{bA}}$ & $6.26 \pm 0.09^{\mathrm{bA}}$ & $6.42 \pm 0.04^{\mathrm{bA}}$ & $6.62 \pm 0.06^{\mathrm{bA}}$ \\
\hline & 15 & $6.24 \pm 0.07^{\mathrm{aB}}$ & $6.93 \pm 0.09^{\mathrm{bB}}$ & $6.62 \pm 0.10^{\mathrm{aA}}$ & $6.35 \pm 0.08^{\mathrm{aA}}$ & $5.88 \pm 0.10^{\mathrm{cB}}$ \\
\hline & 30 & $6.52 \pm 0.07^{\mathrm{aB}}$ & $7.13 \pm 0.09^{\mathrm{bB}}$ & $6.77 \pm 0.11^{\mathrm{aA}}$ & $5.09 \pm 0.07^{\mathrm{cB}}$ & $3.32 \pm 0.02^{\mathrm{dC}}$ \\
\hline \multirow{3}{*}{ Escherichia coli } & 0 & $3.90 \pm 0.00^{\mathrm{aA}}$ & $3.90 \pm 0.00^{\mathrm{aA}}$ & $3.90 \pm 0.00^{\mathrm{aA}}$ & $0^{\mathrm{bA}}$ & $0^{\mathrm{bA}}$ \\
\hline & 15 & $4.14 \pm 0.00^{\mathrm{aB}}$ & $5.72 \pm 0.11^{\mathrm{bB}}$ & $3.90 \pm 0.00^{\mathrm{cA}}$ & $0^{\mathrm{dA}}$ & $0^{\mathrm{dA}}$ \\
\hline & 30 & $4.39 \pm 0.07^{\mathrm{aB}}$ & $5.19 \pm 0.06^{\mathrm{bB}}$ & $3.70 \pm 0.00^{\mathrm{cA}}$ & $0^{\mathrm{dA}}$ & $0^{\mathrm{dA}}$ \\
\hline \multirow{3}{*}{$\begin{array}{c}\text { Salmonella enterica ser. } \\
\text { Typhimurium ATCC } \\
14028\end{array}$} & 0 & $4.74 \pm 0.00^{\mathrm{aA}}$ & $4.57 \pm 0.04^{\mathrm{aA}}$ & $4.73 \pm 0.00^{\mathrm{aA}}$ & $4.52 \pm 0.09^{\mathrm{aA}}$ & $0^{\mathrm{bA}}$ \\
\hline & 15 & $4.75 \pm 0.00^{\mathrm{aA}}$ & $4.78 \pm 0.10^{\mathrm{aA}}$ & $4.45 \pm 0.06^{\mathrm{aA}}$ & $3.90 \pm 0.06^{\mathrm{bB}}$ & $0^{\mathrm{cA}}$ \\
\hline & 30 & $4.93 \pm 0.00^{\mathrm{aA}}$ & $5.17 \pm 0.04^{\mathrm{bA}}$ & $4.63 \pm 0.00^{\mathrm{aA}}$ & $0^{\mathrm{cC}}$ & $0^{\mathrm{cA}}$ \\
\hline \multirow{3}{*}{ Staphylococcus aureus } & 0 & $4.55 \pm 0.08^{\mathrm{aA}}$ & $4.96 \pm 0.00^{\mathrm{aA}}$ & $4.18 \pm 0.12^{\mathrm{aA}}$ & $4.49 \pm 0.09^{\mathrm{aA}}$ & $3.73 \pm 0.00^{\mathrm{bA}}$ \\
\hline & 15 & $5.07 \pm 0.21^{\mathrm{aB}}$ & $5.44 \pm 0.02^{\mathrm{aB}}$ & $5.75 \pm 0.11^{\mathrm{aB}}$ & $4.15 \pm 0.07^{\mathrm{bA}}$ & $0^{\mathrm{cB}}$ \\
\hline & 30 & $5.20 \pm 0.00^{\mathrm{aB}}$ & $5.54 \pm 0.12^{\mathrm{aB}}$ & $5.72 \pm 0.01^{\mathrm{aB}}$ & $3.90 \pm 0.07^{\mathrm{bB}}$ & $0^{\mathrm{cB}}$ \\
\hline
\end{tabular}

Values are expressed as mean \pm SD. Values with different lowercase superscript within the same row while values with different uppercase superscript within the same columns are significantly different $(\mathrm{p}<0.05)$.

and $S$. aureus were directly killed after treatment at 0 min, as well as at room temperature, they were directly killed except $S$. aureus that was totally killed after 15 mins. The concentration of extract at $0.50 \%$ had lethal activity against $E$. coli and Salmonella at $0 \mathrm{~min}$ and 15 mins at chiller temperature, respectively. The same was observed for room temperature, but Salmonella was killed after 30 mins. The $0.05 \%$ concentration showed some inhibition activities, but no lethality was recorded during treatment. On a contrary, $0.50 \%$ of concentration was the MIC value for the tested lab bacteria, but this concentration was lethal for natural bacteria.

There was a study that focused on oleifera leaves (MO) extract to treat marinated chicken fillet (Eldin et al., 2019). MO extract was adjusted into different concentrations to investigate its antimicrobial activity against E. coli, Salmonella and $S$. aureus by injecting each pathogen to wash the UV treated chicken breasts cubes. The results showed that microorganism at $6 \%$ of concentration (the highest concentration) was able to reduce the number of $E$. coli, Salmonella from $7 \log _{10}$ to 5.25 $\log _{10}$ and 6.30 $\log _{10}$ to $5.50 \log _{10} 5.50$ within eight days of treatment respectively, while $S$. aureus was reduced from $\log 7$ to $\log 5.80$ within four days. $S$. aureus was later recovered to be $7 \log _{10}$ in the last four days of treatment. It was noted that more effective activities of TLE happened because even at $0.50 \%$ of concentration, no colony of $E$. coli or Salmonella grew within 30 mins for treating raw chicken meat, while $S$. aureus was inhibited at the same concentration and exposing time. Another study used Syzygium antisepticum leaves extract as an antistaphylococcal 
agent to increase the shelf life of cooked chicken by injecting cooked chicken meat with $S$. aureus after meat samples were dipped in the extract at different concentrations at 4, 10 and $25^{\circ} \mathrm{C}$ (Yuan and Yuk, 2018). The results discovered that $S$. aureus was at the highest concentration of extract which was $38 \mathrm{mg} / \mathrm{mL}$. In other words, it could survive at $25^{\circ} \mathrm{C}$ after $24 \mathrm{hrs}$ of treatment, while it was found to have inhibition activity up to five days of treating the chicken samples at 4 and $10^{\circ} \mathrm{C}$, as well as keeping the bacterial $\log$ between $4 \log _{10}$ and 3 $\log _{10}$. In the present study, treatment was on raw chicken meat. It was found that at $4{ }^{\circ} \mathrm{C}$ or room temperature, taro leaves extract $50 \mathrm{mg} / \mathrm{mL}$ had the ability to kill all-natural $S$. aureus live on chicken, while $5 \mathrm{mg}$ / $\mathrm{mL}$ inhibited the bacterial growth within 30 mins of treatment. However, it seemed that taro leaves extracts were active as antibacterial agents, but their activity was better than other extracts from different plants in the present study.

\section{Conclusion}

In conclusion, taro (Colocasia esculenta) leaves extract showed antibacterial activity against E. coli, $L$. monocytogenes, $S$. enterica ser. Typhimurium., and $S$. aureus. Taro leaves extract could reduce the microbial population in raw chicken meat in concentration, exposure times and temperatures in a dependent manner. Thus, taro leaves extract could be developed as a natural food preservative.

\section{References}

Abdulmumeen, H.A., Risikat, A.N. and Sururah, A.R. (2012). Food: Its preservatives, additives and applications. International Journal of Chemical and Biochemical Sciences, 1, 36-47.

Addis, M. and Sisay, D. (2015). A review on major food borne bacterial illnesses. Journal of Tropical Diseases and Public Health, 3(4), 1-7.

Akter, A., Rahman, S., Morshed, M.T., Hossain, S., Jahan, S., Swarna, A. and Rahmatullah, M. (2013). Evaluation of antihyperglycemic and antinociceptive potential of Colocasia esculenta (L.) Schott (Araceae) leaves. Advances in Natural and Applied Sciences, 7(2), 143-148.

Azwanida, N.N. (2015). A review on the extraction methods use in medicinal plants, principle, strength and limitation. Medicinal and Aromatic Plants, 4(3), 2167-0412.

Bondi, M., Lauková, A., de Niederhausern, S., Messi, P. and Papadopoulou, C. (2017). Natural preservatives to improve food quality and safety. Journal of Food Quality, 2017, $1090932 . \quad$ https:// doi.org/10.1155/2017/1090932

Clinical and Laboratory Standards Institute. (2012). Approved guidelines M11-A8. Methods for the determination of minimal inhibitory concentrations of anaerobic bacteria by agar dilution and broth microdilution. 8th ed. Wayne, Philadelphia, USA: CLSI.

Bubonja-Sonje, M., Giacometti, J. and Abram, M. (2011). Antioxidant and antilisterial activity of olive oil, cocoa and rosemary extract polyphenols. Food Chemistry, 127(4), 1821-1827. https:// doi.org/10.1016/j.foodchem.2011.02.071

Dubey, A., Mishra, N. and Singh, N. (2010). Antimicrobial activity of some selected vegetables. International Journal of Applied Biology and Pharmaceutical Technology, 1(3), 994-999.

Dutta, S. and Aich, B. (2017). A study of antibacterial and antifungal activity of the leaves of Colocasia esculenta linn. International Journal of Pharmaceutical Sciences and Research, 8(3), 11841187.

Eldin, R.M.B., Talaat, D., Elbaba, A.H. and Ibrahim, M.S. (2019) Antibacterial Activity of Some Plant Extracts on Different Bacteria in Chicken Fillet. European Journal of Pharmaceutical and Medical Research, 7(1), 84-95

Fu, Y., Zu, Y., Chen, L., Shi, X., Wang, Z., Sun, S. and Efferth, T. (2007). Antimicrobial activity of clove and rosemary essential oils alone and in combination. Phytotherapy Research, 21(10), 989994. https://doi.org/10.1002/ptr.2179

Geetha, S., Padal, S.B. and Satyavathi, K. (2015). Antimicrobial activity of selected leaf extracts against water borne pathogenesis. Malay Journal of Biosciences, 2(4), 190-193.

Lee, S., Wee, W., Yong, J. and Syamsumir, D., (2011). Antimicrobial, antioxidant, anticancer property and chemical composition of different parts (corm, stem and leave) of Colocasia esculenta extract. Ann Univ Mariae Curie-Sklodowska Pharm, 24(3), 9-16.

Mamman, P.H., Mshelia, W.P., Susbatrus, S.C. and Sambo, K.W. (2013). Antibacterial effects of crude extract of Azadirachta indica against Escherichia coli, Salmonella spp and Staphylococcus aureus. International Journal of Medicine and Medical Sciences, 5(1), 14-18.

Nakade, D., Mahesh, S., Kiran, N. and Vinayak, S. (2013). Phytochemical screening and antibacterial activity of western region wild leaf of Colocasia esculenta. International Research Journal of Biological Sciences, 2(8), 18-21.

Oladosu, P., Isu, N.R., Ibrahim, K., Okolo, P. and 
Oladepo, D.K. (2013). Time kill-kinetics antibacterial study of Acacia nilotica. African Journal of Microbiology Research, 7(46), 52485252. https://doi.org/10.5897/AJMR2013.5889

Palombo, E.A. and Semple, S.J. (2002). Antibacterial activity of Australian plant extracts against methicillin-resistant Staphylococcus aureus (MRSA) and vancomycin-resistant enterococci (VRE). Journal of Basic Microbiology: An International Journal on Biochemistry, Physiology, Genetics, Morphology, and Ecology of Microorganisms, 42(6), 444-448. https://doi.org/10.1002/1521-4028(200212) 42:6<444::AID-JOBM444>3.0.CO;2-8

Pawar, H.A., Choudhary, P.D. and Kamat, S.R. (2018). An overview of traditionally used herb, Colocasia esculenta, as a phytomedicine. Medicinal and Aromatic Plants, 1(7),300- 317. https:// doi.org/10.4172/2167-0412.1000317

Puteh, S.E.W., Netty, D. and Sangaran, G. (2013). Paper review of factors, surveillance and burden of food borne disease outbreak in Malaysia. Malaysian Journal of Public Health Medicine, 13(2), 36-43.

Rukayadi, Y., Shim, J.S. and Hwang, J.K. (2008). Screening of Thai medicinal plants for anticandidal activity. Mycoses, 51(4), 308-312. https:// doi.org/10.1111/j.1439-0507.2008.01497.x

Rukayadi, Y., Lee, K., Han, S., Yong, D. and Hwang, J.K. (2009). In vitro activities of panduratin A against clinical Staphylococcus strains. Antimicrobial Agents and Chemotherapy, 53(10), 4529-4532. https://doi.org/10.1128/AAC.00624-09

Sharma, S. (2015). Food preservatives and their harmful effects. International Journal of Scientific and Research Publications, 5(4), 1-2.

Singh, B., Namrata, K.L. and Dwivedi, S.C. (2011). Antibacterial and antifungal activity of Colocasia esculenta aqueous extract: an edible plant. Journal of Pharmacy Research, 4(5), 1445-1459.

Yuan, W. and Yuk, H.G. (2018). Antimicrobial efficacy of Syzygium antisepticum plant extract against Staphylococcus aureus and methicillin-resistant $S$. aureus and its application potential with cooked chicken. Food microbiology, 72, 176-184. https:// doi.org/10.1016/j.fm.2017.12.002

Yusoff, N.A.H., Sanuan, F.M. and Rukayadi, Y. (2015). Cosmos caudatus Kunth. extract reduced number of microflora in oyster mushroom (Pleurotus ostreatus). International Food Research Journal, 22 (5), 1828-1837. 